\title{
Review- The periodontal pathogen Treponema denticola: an atherosclerosis risk
}

\section{factor}

\author{
Revisão - O patógeno periodontal Treponema denticola: um fator de risco para aterosclerose \\ Revisión - El patógeno periodontal Treponema denticola: un factor de riesgo para la aterosclerosis
}

Pâmela Beatriz do Rosário Estevam dos Santos

ORCID: https://orcid.org/0000-0001-9600-9058

São Paulo State University, Brazil Universidade Paulista, Brazil

E-mail:pamela_beatriz79@hotmail.com

Patrícia Michelle Nagai De Lima ORCID: https://orcid.org/0000-0001-7870-0005 São Paulo State University Brazil E-mail: patricia.nagai@unesp.br

Ana Luiza do Rosário Palma ORCID: https://orcid.org/0000-0001-9478-8123

São Paulo State University, Brazil Universidade Paulista, Brazil E-mail: ana.rosario@unesp.br

Amjad Abu Hasna

ORCID: https://orcid.org/0000-0002-1112-985X

São Paulo State University, Brazil

E-mail: d.d.s.amjad@gmail.com

Rodnei Dennis Rossoni

ORCID: https://orcid.org/0000-0002-9977-3040

São Paulo State University, Brazil

E-mail: rodnei.rossoni@unesp.br

Juliana Campos Junqueira

ORCID: https://orcid.org/0000-0001-6646-6856 São Paulo State University, Brazil

E-mail: Juliana.junqueira@unesp.br

Luciane Dias de Oliveira

ORCID: https://orcid.org/0000-0002-5465-9551

São Paulo State University, Brazil

E-mail: Luciane.oliveira@unesp.br

\begin{abstract}
Objective: Treponema denticola "T. denticola" is a pathogen associated with periodontal diseases that exhibits capacity for adherence, invasion, and colonization of host tissues, which allows alternating its location and damage in different sites of human body. This review aimed to discuss different studies that detected T. denticola in atherosclerotic plaques, demonstrating the importance of periodontal disease on the systemic health and the necessity of exploring the outcome of this colonization apart from the oral cavity. Methodology: Fifty-five studies were identified and gathered in this review according to the following topics: Periodontal disease, atherosclerosis and $T$. denticola. In vitro and in vivo studies published between 2002 and 2020 were searched on PubMed, raising relevant insights about the role of $T$. denticola and its association with the systemic disease, atherosclerosis, focusing on the bacterial tissue invasion and development of atherosclerosis. Results: After bibliographic review, it was possible to identify studies demonstrating the presence of $T$. denticola and other oral pathogens in cardiac or vascular tissues and in blood serum, as well, there is research in which other evidence of a relationship with atherosclerosis is shown. Conclusion: The invasion of periodontal pathogens and its toxins associated to the host's immune and inflammatory response may contribute to the development of atherosclerosis.
\end{abstract}

Keywords: Treponema denticola; Periodontal diseases; Atherosclerosis.

\section{Resumo}

Objetivo: Treponema denticola “T. denticola” é um patógeno associado a doenças periodontais que apresenta capacidade de aderência, invasão e colonização dos tecidos do hospedeiro, o que permite alternar sua localização e danos em diferentes locais do corpo humano. Esta revisão tem por objetivo discutir diferentes estudos que detectaram T. denticola em placas ateroscleróticas, demonstrando a importância da doença periodontal na saúde sistêmica e a necessidade de explorar o desfecho dessa colonização além da cavidade oral. Metodologia: Cinquenta e cinco estudos 
foram identificados e agregados nesta revisão de acordo com os seguintes tópicos: Doença periodontal, aterosclerose e T. denticola. Estudos in vitro e in vivo publicados entre 2002 e 2020 foram pesquisados no PubMed, levantando insights relevantes sobre o papel do $T$. denticola e sua associação com a doença sistêmica, aterosclerose, focando na invasão bacteriana do tecido e o desenvolvimento da aterosclerose. Resultados: Após revisão bibliográfica, foi possível identificar estudos que demonstram a presença de $T$. denticola e outros patógenos orais em tecidos cardíacos ou vasculares e no soro sanguíneo, bem como, há pesquisas em que são apresentadas outras evidências de relação com a aterosclerose. Conclusão: A invasão de patógenos periodontais e suas toxinas associadas à resposta imune e inflamatória do hospedeiro podem contribuir para o desenvolvimento da aterosclerose.

Palavras-chave: Treponema denticola; Doenças periodontais; Aterosclerose.

\section{Resumen}

Objetivo: Treponema denticola "T. denticola" es un patógeno asociado a las enfermedades periodontales que tiene la capacidad de adherencia, invasión y colonización de los tejidos del huésped, lo que permite alternar su ubicación y daño en distintas localizaciones del cuerpo humano. Esta revisión tiene como objetivo discutir diferentes estudios que detectaron $T$. denticola en placas ateroscleróticas, demostrando la importancia de la enfermedad periodontal en la salud sistémica y la necesidad de explorar el resultado de esta colonización más allá de la cavidad oral. Metodología: Se identificaron y agregaron cincuenta y cinco estudios en esta revisión de acuerdo con los siguientes temas: Enfermedad periodontal, aterosclerosis y T. denticola. Los estudios in vitro e in vivo publicados entre 2002 y 2020 se investigaron en PubMed, lo que generó conocimientos relevantes sobre el papel de $T$. denticola y su asociación con enfermedades sistémicas, aterosclerosis, centrándose en la invasión de tejido bacteriano y el desarrollo de aterosclerosis. Resultados: Luego de una revisión bibliográfica, fue posible identificar estudios que demuestran la presencia de $T$. denticola y otros patógenos orales en tejidos cardíacos o vasculares y en suero sanguíneo, así como, hay investigaciones en las que se presentan otras evidencias de relación con la aterosclerosis. Conclusión: La invasión de patógenos periodontales y sus toxinas asociadas con la respuesta inmunitaria e inflamatoria del huésped puede contribuir al desarrollo de la aterosclerosis.

Palabras clave: Treponema denticola; Enfermedades periodontales; Aterosclerosis.

\section{Introduction}

Atherosclerosis, a cardiovascular disease, is one of the most common cause of death in the world alerting the need to control it (Spacek, Zemanek, Hutyra, Sluka, \& Taborsky, 2018). Some modern techniques were suggested to treat this kind of disease enabling to extend life expectancy of patients. However, in some cases, invasive surgery is needed (Libby et al., 2019).

Atherosclerosis is an inflammatory chronic disease capable of triggering other conditions with high mortality rate (Kobiyama \& Ley, 2018). It causes arteries blockage or occlusion due to the atheromatous plaque formation. Furthermore, it may result in myocardial infarction due to the formation of a thrombus or blood clot (Gisterå \& Hansson, 2017; Spacek et al., 2018).

Smoking, hypertension, diabetes mellitus, hyperlipidemia, male sex and advanced age are considered as risk factors for atherosclerosis (Herrington et al., 2016; Libby et al., 2019; Toyofuku et al., 2011). As well, recent studies suggested the periodontal disease as a risk factor to cardiovascular diseases because of the endothelial damage caused by the periodontal pathogens toxins (D. M. Herrington et al., 2018; Mahendra, Mahendra, Kurian, Jaishankar, \& Mythilli, 2009; Raffaelli et al., 2010). This damage associated to the host response (immunologic and inflammatory) contribute to the development of these conditions (Bui et al., 2019).

Periodontal diseases are caused by bacterial growth and accumulation because of poor oral hygiene and result in periodontium (gingiva, alveolar bone, periodontal ligament, and cementum) inflammation, and in more advanced stages, may lead to the destruction of the supporting structures of the teeth (Aquino, Lima, Paiva, Rôças, \& Siqueira, 2011; Deinzer et al., 2005; Dentino, Lee, Mailhot, \& Hefti, 2013; Gangula et al., 2015; Mahendra et al., 2009; Rivera et al., 2013; Verma et al., 2010). Periodontal diseases affect about 5 to $20 \%$ of the global population and are among the most common chronic infections (Deinzer et al., 2005; Gangula et al., 2015; Genco \& Borgnakke, 2013; Heidari, Moudi, \& Mahmoudzadeh-Sagheb, 2019; Maixner et al., 2014; Torrungruang, Jitpakdeebordin, Charatkulangkun, \& Gleebbua, 2015; Velsko et al., 2015; Verma et al., 2010). 
The red-complex, Treponema denticola “T. denticola”, Porphyromonas gingivalis "P. gingivalis" and Tanerella forsythia "T. forsythia", are considered as subgingival plaque colonizers and the most virulent periodontal pathogens (Kokubu, Inoue, \& Ishihara, 2018; Mohanty et al., 2019; Nagao \& Tanigawa, 2019). T. denticola is a Gram-negative anaerobic spirochete that shows ordinarily four periplasmic flagella, which facilitate its motility even in a viscous environment (Abiko, Nagano, Yoshida, \& Yoshimura, 2014; Dahlen \& Preus, 2017; Mohanty et al., 2019; Nagano, Hasegawa, Yoshida, \& Yoshimura, 2017). This motility may be involved with biofilm formation of $P$. gingivalis that is considered the major pathogen of periodontitis ( $\mathrm{Ng}$ et al., 2019; Radhakrishnan et al., 2019). T. denticola is one of the most resistant bacteria frequently identified in primary dentition infection, while in adults is frequently isolated from periodontal pockets and it initiates dysregulation of inflammation and tissue homeostasis, thus, it is highly associated with periodontal diseases. Nevertheless, its pathogenic roles still need to be better established (Kaushik et al., 2015; Loyola-Rodriguez et al., 2014; Miao et al., 2014; Mo et al., 2013; Mohanty et al., 2019).

\section{Methodology}

In this literature review, fifty-five studies were identified and gathered according to the following topics: Periodontal disease, atherosclerosis and T. denticola. In vitro and in vivo studies published between 2002 and 2020 were searched on PubMed, raising relevant insights about the role of $T$. denticola and its association with the systemic disease, atherosclerosis, focusing on the bacterial tissue invasion and development of atherosclerosis.

\section{Results and Discussion}

\subsection{Virulence factors and tissue penetration of $T$. denticola}

Virulence factors may vary among the different species or strains according to bacterial cell composition, structural proteins, toxins, and other molecules released into the host tissues. Usually, the motility is not classified as a bacterial virulence factor, however, considering $T$. denticola and its role in disease progress, this characteristic is essential for its pathogenicity (Dashper, Seers, Tan, \& Reynolds, 2011; Ng et al., 2019). In this context, Nagano et al., (2017) studied the rotation rate of four T. denticola strains (ATCC 35404, ATCC 35405, ATCC 33520 and ATCC 33521) by phase-contrast microscopy and slow motion reproduced films; the motility by measuring the turbidity of soft agar medium plaques; and transmission electron microscopy (TEM) to observe the cells. The results showed divergences between the tested strains, ATCC35404 showed the greatest motility, followed by ATCC33521. Conversely, ATCC35405 and ATCC33520 strains showed low motility. For diffusivity, ATCC35404 strain had the largest turbid plaques, followed by ATCC33521. Observation with TEM showed that protruding extracellular flagellar filaments were frequent in strains ATCC35405 and ATCC33520, conversely, they were occasionally detected in ATCC33521 and not found at all in ATCC35404.

In order to investigate the influence of $T$. denticola motility on synergism with $P$. gingivalis, two mutant strains that did not show motility were produced. The first strain lacked the gene in charge of producing the protein for the periplasmic flagellum ( $\triangle \mathrm{flgE}$ ) formation and the second strain was absent from the component that triggers the movement of the flagellum $(\Delta$ motB) and compared its results with a non-mutant wild-type strain. The results showed that the coaggregation between $T$. denticola $\Delta$ motB and $P$. gingivalis was not affected by the lack of the gene. However, the coaggregation between $T$. denticola $\Delta \mathrm{flgE}$ and $P$. gingivalis was smaller and slower when compared to non-mutant strains. Still, in the formation of monospecies biofilm, both mutant strains formed a biofilm with significantly smaller biomass than the wild type strain. In the biofilm formation between $T$. denticola and $P$. gingivalis, $T$. denticola $\Delta$ flgE showed a $5 \mathrm{x}$ reduction in biomass when compared to a non-mutant strain. While $T$. denticola $\Delta$ motB showed a biomass twice smaller when compared to a wild strain. Thus, the 
flagella and its motility play an important role in synergism with other species (Ng et al., 2019).

Furthermore, Ruby et al., (2018) compared the strain ATCC 35405 of $T$. denticola with the isogenic mutant strain HL51 which does not present flagella. The results showed that the presence of flagella in $T$. denticola has a great influence on the inflammatory response by stimulating the production of TNF- $\alpha$, IL-1 $\beta$, IL-6, IL-10 and IL-12 by in peripheral human blood mononuclear cells, while the mutant strain HL51 showed a significant reduction in the ability to activate the release of these cytokines.

Some pathogens can cause inflammatory cell death and release of molecules of endogenous danger in infected cells, which can contribute to the pathogenesis and progression of the disease by increasing immune and inflammatory responses (Jun, Jung, \& Choi, 2017). The same study investigated the ability of periodontal pathogens $T$. denticola, $P$. gingivalis, and $T$. forsythia to induce these phenomena in macrophages derived from the monocyte THP-1 lineage by different methods and tests including the Western blotting; the lactate dehydrogenase LDH assay using LDH Cytotoxicity assay kit; the extracellular ATP (adenosine triphosphate) concentrations; the extracellular uric acid concentrations; and staining by annexin V (AV) and propidium iodide (PI). The authors concluded that pathogens are capable of activating inflammatory caspases that can induce cell death from pyroptosis. $T$. denticola stood out with a greater increase in cell lysis compared to the others and, like $T$. forsythia, it also seemed to induce apoptosis and release of HSP60 protein and fibronectin. Pathogens also significantly increased extracellular ATP (which induces caspase-1 activation), thus indicating an increase in endogenous danger signs.

One of its most studied proteins, dentilisin, works as a porin and has the capacity to bind to a variety of host proteins favoring the virulence of bacteria. By interrupting or modulating the host's intercellular signaling pathways and degrading host cell-matrix proteins, dentilisin contributes to the progression of the disease. It is involved in nutrient uptake, coaggregation, activation of the complement system, escape strategy of the host immune response, protein degradation and cell invasion (Dashper et al., 2011; Kikuchi \& Ishihara, 2021). It is already considered that the variation in activity between strains may have epidemiological value and can influence the disease, therefore, higher levels of dentilisin activity characterizes a more virulent strain (Miller et al., 2014). Inagaki et al., (2016) compared four strains of T. denticola with and without dentilisin, and founded that strains with dentilisin have a greater capacity to invade the human gingival epithelial cells.

In addition to its important role in nutrient uptake, dentilisin is also essential for tissue invasion and cleavage of proteins released by the immune response (Fenno, 2012). Marttila et al., (2014) analyzed its location in ex vivo chronic periodontitis tissues. Through PCR (Polymerase Chain Reaction) and immunohistochemical analysis with visualization under a light microscope it was observed that 12 of the 25 samples showed T. denticola in the PCR and dentilisin was detected in all of these samples, as well as in three patients with negative result in PCR (Marttila et al., 2014). In the same study, Dentilisin was found in the connective tissue in 2 of the 12 samples, in the epithelium in 7 samples, and in both the connective tissue and epithelium in the other three samples. It was found irregular, loose and mainly intracellular in the epithelium in depth bands indicating the ability of tissue invasion by the pathogen.

It is already established that dentilisin and Msp protein play an important role in the development of periodontal disease (Fenno, 2012). Inagaki et al., (2016) investigated the role of these proteins in the cellular invasion ability of $T$. denticola using the strains ATCC 35405, mutant deficient in Msp (DMSP3) and mutant deficient in dentilisin (K1), through standard antibiotic protection assay, it was observed that the invasion of T. denticola ATCC 35405 was 3\%, DMSP3 was $2.36 \%$ and $\mathrm{K} 1$ was $1.31 \%$, indicating the importance of these proteins in the pathogen invasion. Since cell invasion can delay wound healing, the authors also studied cell migration: immortalized human gingival epithelial cells (HGEC) were scratched with plastic and incubated with each strain to determine healing in vitro. It was observed that cell migration was lower with the infection of ATCC 35405 compared to cells uninfected or infected with mutant deficient in Msp or dentilisin, indicating 
interferences of these proteins especially of detilisin in the healing process.

To demonstrate that periodontal bacteria invade gingival tissue, Velsko et al., (2015) employed fluorescent hybridization in situ, where numerous specimens of $T$. denticola were detected in gingival connective tissue of infected mice and deficient in $\beta 6$ integrin (predisposing to increased periodontal inflammation), while $P$. gingivalis was detected in its epithelial tissue. Kikuchi et al., (2018) studied induced infection by T. denticola, ATCC 35405 and mutant without dentilisin (K1) strains in Madin-Darby canine kidney cells (MDCK) to investigate the role of the bacteria under the junction of the epithelial barrier. The results suggested that $T$. denticola is capable of invading even deeper cells through the degradation of epithelial junction proteins, ZO-1 (Zonula occludens protein) and claudin-1. This invasion capacity, even in deeper tissues has an important impact on the development and progression of periodontal disease and supports the hypothesis of systemic spread of this bacterium (Chu et al., 2020).

As explained above, dozens of virulence determinants were identified in T. denticola, (Dashper et al., 2011; Ishihara, 2010). The virulence factors are related to the most diverse roles of performance and one of the most interesting is related to Glutathione catabolism (Chu et al., 2020). T. denticola is one of two bacteria responsible for periodontal disease that demonstrate what is known as the complete three-step enzyme pathway (GTSP), which catabolizes glutathione into hydrogen sulfide $\left(\mathrm{H}_{2} \mathrm{~S}\right.$ ) (Paolicchi et al., 2002; Pastore et al., 2003). Chu et al., (2020) observed in the literature that one of the related metabolic pathways may play an extremely important role in the pathogenesis of $T$. denticola, since the so-called GTSP metabolizes glutathione into $\mathrm{H}_{2} \mathrm{~S}$. It is known that the levels of two thiol compounds are of interest for study since the literature points out that the levels differ in the gingival fluid of healthy individuals when compared to individuals with periodontal disease.

In order to demonstrate that glutathione catabolism by GTSP acts as an important virulence factor, Chu et al., (2020) carried out the construction of a mutant strain, through allelic substitution to make a deletion mutant ( $\Delta$ ggt) in the gene encoding the first enzyme in GTSP. The study is a pioneer in the area. According to the same study the mutant cannot produce $\mathrm{H}_{2} \mathrm{~S}$ from glutathione, since it does not have an enzymatic activity of gamma-glutamyl transferase (GGT). The enzymatic activity resulting from hemolysis and hemoxidation becomes reduced when compared to the strain ATCC 33520 and the mutant strain. The mutant lost the ability to grow aerobically when incubated with glutathione. The $\Delta$ ggt bacterium with glutathione causes less cell death in human gingival fibroblasts (hGFs) in vitro than the other strain analyzed (Chu et al., 2020).

\subsection{T. denticola and Atherosclerosis}

According to the Pan American Health Organization (PAHO), cardiovascular diseases are the leading cause of death in the world, where people die annually because of these diseases more than any others. PAHO estimates that 17.7 million people died of cardiovascular disease in 2015 , representing $31 \%$ of all deaths globally on that year. Of these deaths, 7.4 million are due to cardiovascular disease and 6.7 million are due to strokes. The incidence of cardiovascular disease occurs in low- and middle-income countries (Middeke, 2019).

The etiology of the disease is multifactorial, nowadays, it addresses age, sex, diet, smoking (Gu et al., 2019), hypertension, diabetes, dyslipidemia, homocysteine dosage, obesity, family history (Middeke, 2019), genetic factors (Rizzacasa et al., 2019), as well as the action of microorganisms of the oral mucosa. Currently, there are several studies show that viral and bacterial infections have pro-atherogenic properties, since many microorganisms were detected in the walls of atherosclerotic blood vessels including $P$. gingivalis, the main pathogen of periodontitis. Moreover, the presence of pathogenspecific antibodies is also linked to atherosclerosis ( $\mathrm{Li}, \mathrm{Xia}, \& \mathrm{Hu}, 2020)$. The aspects related to the microorganism mentioned above may interfere with the atherosclerotic disease but the main cause of the development of the atherosclerotic plaque (a 
fibro-proliferative inflammatory response) is the endothelial damage. The disease can also be caused by invasion, proliferation and accumulation of cells and surrounding blood with the deposition of connective tissue and lipids, in addition to the possibility of adherence of phagocyte pathogens (Chukkapalli et al., 2014; Mahendra et al., 2009).

As previously described, T. denticola has important virulence factors and properties that favor its pathogenic action and has demonstrated its capacity for tissue invasion, which can also occur with phagocyte transport (Mahendra et al., 2009). Therefore, in order to identify new harmful interferences of the species that go beyond periodontal disease, it is essential to study the location and effects of these pathogens on other tissues and organs (Misaki et al. 2019).

Oral bacteria are often identified in bacteremia with the possibility of involvement in vascular diseases. Studies show that beyond systemic infection, after oral colonization $T$. denticola and other oral pathogens can sow organs such as the heart and large arteries through the bloodstream where they penetrate and produce endotoxins such as lipopolysaccharides (LPS) that generate inflammatory cytokines by regulating endothelial adhesion molecules and inducing a prothrombotic environment (Bale, Doneen, \& Vigerust, 2017; Chukkapalli et al., 2014; Mahendra et al., 2009).

Since this disease is so important, several studies investigated its relationship with the microorganism (Aquino et al., 2011; Toyofuku et al., 2011; Velsko et al., 2015). Mahendra et al., (2009) selected 51 patients with chronic periodontitis from the Institute of Cardiovascular Disease in Chennai (India), all suffering from Coronary Artery Disease and are going to undergo a coronary artery bypass graft surgery. Samples of subgingival plaque were obtained 24-hours before the surgery and the samples of atherosclerotic plaques were obtained during the surgery. Using PCR technique, it was observed that in the subgingival plaque, T. denticola was found in $66.66 \%$ and P. gingivalis in $64.71 \%$ of the samples, while in the atherosclerotic plaque, T. denticola was detected in $49.01 \%$ and $P$. gingivalis in $45.10 \%$ of the samples. In both subgingival and atherosclerotic plaques, $T$. denticola was found in $39.21 \%$ and $P$. gingivalis in $39.22 \%$ of the cases.

Soto-Barreras et al., (2013) studied the association between periodontal disease and peripheral arterial disease (PAD) at San Luis Potosí University (Mexico). Sixty individuals were involved in the study, thirty of them have peripheral arterial disease and the others were healthy. T. denticola and other microorganisms (S. mutans, P. gingivalis, T. forsythia and P. intermedia) were detected by PCR in both subgingival biofilm and in blood serum of cubital vein. In which solely, $P$. gingivalis was the most prevalent microorganism in patients with PAD comparing to the healthy individuals.

Rivera et al., (2013) used a mixture of T. denticola, P. gingivalis and T. forsythia with carboxymethyl cellulose and PBS for oral infection in mice deficient in Apolipoprotein E, "ApoE (null)". The infection was applied for 4 days every two weeks, for a total of 16 weeks to simulate chronic exposure. Samples of the microbiota were collected 7 days after each infection. After 16 weeks of infection, the aorta, heart, maxilla, mandible, among other structures, were collected and microorganisms was detected since the 2nd week in oral samples. T. denticola was found in the thoracic aorta of 12 of the 15 animals in the experimental group, in addition to palatal bone loss and increased invasion of inflammatory cells and plaque proportional to the number of bacterial species in cross-sections of the ascending aorta. No bacterial genomic DNA was found in other studied organs (liver, spleen and kidneys).

Chukkapalli et al., (2014) evaluated the relation between periodontal disease induced with T. denticola and atherosclerosis in hyperlipidemic ApoE mice. Chronic periodontitis is already known to contribute to the development of hyperlipidemia (Chukkapalli et al., 2014; Velsko et al., 2015). T. denticola was administered orally to the mice every three weeks for four days until euthanasia at the 12th or 24th week. After the second infection 50\% of the animals were colonized, while at the seventh infection, this value increased to 90\% (Chukkapalli et al., 2014). Accelerated atherosclerosis associated with increased plaque area was also indicated, in addition to the identification of bacteria in primary location in gingival tissue and in aortic tissues (at 12 and 24 weeks) revealing invasiveness and dissemination to the circulation with subsequent 
penetration into vascular tissues. It is important to note that the study also demonstrated an increase in the immune response associated with infection, alteration of cytokines, increase in low density lipoproteins, alteration of gene expression and reduction of nitric oxide, other factors associated with infection by the pathogen and atherosclerotic disease (Chukkapalli et al., 2014). These results indicate that the risk associated with the microorganism is not limited to periodontal disease, but also affects other tissues and organs, which further expands the importance of investigating the characteristics of this species.

Another important study was conducted by Velsko et al., (2015), in which $\beta 6$-deficient mice were used, assuming that with periodontal disease there could be a systemic spread of bacteria, consequently altering homeostasis to the point of developing atherosclerotic plaque without the need for a hyperlipidemic condition. 26-week-old mice (mutant and wild) were treated with antibiotics to reduce oral flora, so the bacterial species P. gingivalis, T. denticola, T. forsythia and Fusobacterium nucleatum were inoculated for four consecutive days a week, every three weeks for 24 weeks, and one week after each infection, samples were taken from the gingival cavity. The mice developed severe periodontal disease, and using morphometric histological analysis, a minimal plaque was detected in the aortic arch in all groups, despite being greater in the mutant than in the wild mice. In addition, DNA from the four species used was found in the hearts and aortas of the infected mutant rats, and, although few wild aortas were found to be positive, all four species were detected.

After bibliographic review, it was possible to identify studies demonstrating the presence of T. denticola and other oral pathogens in cardiac or vascular tissues and in blood serum (Chukkapalli et al., 2014; Li et al., 2020; Mahendra et al., 2009; Rivera et al., 2013; Soto-Barreras et al., 2013; Velsko et al., 2015), as well, there is research in which other evidence of a relationship with atherosclerosis is shown (Chukkapalli et al., 2014; Rivera et al., 2013).

\section{Conclusion}

The invasion of periodontal pathogens and its toxins associated to the host's immune and inflammatory response may contribute to the development of atherosclerosis.

\section{Acknowledgments}

The authors deny any conflict of interest.

\section{References}

Abiko, Y., Nagano, K., Yoshida, Y., \& Yoshimura, F. (2014). Characterization of Treponema denticola mutants defective in the major antigenic proteins, Msp and TmpC. Plos One, 9(11), e113565. 10.1371/journal.pone.0113565

Aquino, A. R. L., Lima, K. C., Paiva, M. S., Rôças, I. N., \& Siqueira, J. F. (2011). Molecular survey of atheromatous plaques for the presence of DNA from periodontal bacterial pathogens, archaea and fungi. Journal of periodontal research, 46(3), 303-309. 10.1111/j.1600-0765.2010.01343.x

Bale, B. F., Doneen, A. L., \& Vigerust, D. J. (2017). High-risk periodontal pathogens contribute to the pathogenesis of atherosclerosis. Postgraduate Medical Journal, 93(1098), 215-220. 10.1136/postgradmedj-2016-134279

Bui, F. Q., Almeida-da-Silva, C. L. C., Huynh, B., Trinh, A., Liu, J., Woodward, J., \& Ojcius, D. M. (2019). Association between periodontal pathogens and systemic disease. Biomedical journal, 42(1), 27-35. 10.1016/j.bj.2018.12.001

Chu, L., Wu, Y., Xu, X., Phillips, L., \& Kolodrubetz, D. (2020). Glutathione catabolism by Treponema denticola impacts its pathogenic potential. Anaerobe, 62, 102170. 10.1016/j.anaerobe.2020.102170

Chukkapalli, S. S., Rivera, M. F., Velsko, I. M., Lee, J.-Y., Chen, H., Zheng, D., \& Kesavalu, L. (2014). Invasion of oral and aortic tissues by oral spirochete Treponema denticola in ApoE(-/-) mice causally links periodontal disease and atherosclerosis. Infection and Immunity, 82(5), 1959-1967. 10.1128/IAI.0151114

Dahlen, G., \& Preus, H. R. (2017). Low antibiotic resistance among anaerobic Gram-negative bacteria in periodontitis 5 years following metronidazole therapy. Anaerobe, 43, 94-98. 10.1016/j.anaerobe.2016.12.009

Dashper, S. G., Seers, C. A., Tan, K. H., \& Reynolds, E. C. (2011). Virulence factors of the oral spirochete Treponema denticola. Journal of Dental Research, 90(6), 691-703. 10.1177/0022034510385242 
Deinzer, R., Granrath, N., Spahl, M., Linz, S., Waschul, B., \& Herforth, A. (2005). Stress, oral health behaviour and clinical outcome. British journal of health psychology, 10(Pt 2), 269-283. 10.1348/135910705X26858

Dentino, A., Lee, S., Mailhot, J., \& Hefti, A. F. (2013). Principles of periodontology. Periodontology 2000, 61(1), 16-53. 10.1111/j.1600-0757.2011.00397.x

Fenno, J. C. (2012). Treponema denticola interactions with host proteins. Journal of oral microbiology, 4. doi:10.3402/jom.v4i0.9929

Gangula, P., Ravella, K., Chukkapalli, S., Rivera, M., Srinivasan, S., Hale, A., \& Kesavalu, L. (2015). Polybacterial Periodontal Pathogens Alter Vascular and

Gut BH4/nNOS/NRF2-Phase II Enzyme Expression. Plos One, 10(6), e0129885. 10.1371/journal.pone.0129885

Genco, R. J., \& Borgnakke, W. S. (2013). Risk factors for periodontal disease. Periodontology 2000, 62(1), 59-94. 10.1111/j.1600-0757.2012.00457.x

Gisterå, A., \& Hansson, G. K. (2017). The immunology of atherosclerosis. Nature Reviews. Nephrology, 13(6), 368-380. 10.1038/nrneph.2017.51

Gu, Z., Singh, S., Niyogi, R. G., Lamont, G. J., Wang, H., Lamont, R. J., \& Scott, D. A. (2019). Marijuana-Derived Cannabinoids Trigger a CB2/PI3K Axis of Suppression of the Innate Response to Oral Pathogens. Frontiers in immunology, 10, 2288. 10.3389/fimmu.2019.02288

Heidari, Z., Moudi, B., \& Mahmoudzadeh-Sagheb, H. (2019). Immunomodulatory factors gene polymorphisms in chronic periodontitis: an overview. BMC oral health, 19(1), 29. 10.1186/s12903-019-0715-7

Herrington, D. M., Mao, C., Parker, S. J., Fu, Z., Yu, G., Chen, L., \& Van Eyk, J. E. (2018). Proteomic architecture of human coronary and aortic atherosclerosis. Circulation, 137(25), 2741-2756. 10.1161/CIRCULATIONAHA.118.034365

Herrington, W., Lacey, B., Sherliker, P., Armitage, J., \& Lewington, S. (2016). Epidemiology of atherosclerosis and the potential to reduce the global burden of atherothrombotic disease. Circulation Research, 118(4), 535-546. 10.1161/CIRCRESAHA.115.307611

Inagaki, S., Kimizuka, R., Kokubu, E., Saito, A., \& Ishihara, K. (2016). Treponema denticola invasion into human gingival epithelial cells. Microbial Pathogenesis, 94, 104-111. 10.1016/j.micpath.2016.01.010

Ishihara, K. (2010). Virulence factors of Treponema denticola. Periodontology 2000, 54(1), 117-135. 10.1111/j.1600-0757.2009.00345.x

Jun, H.-K., Jung, Y.-J., \& Choi, B.-K. (2017). Treponema denticola, Porphyromonas gingivalis, and Tannerella forsythia induce cell death and release of endogenous danger signals. Archives of Oral Biology, 73, 72-78. 10.1016/j.archoralbio.2016.09.010

Kaushik, S. N., Scoffield, J., Andukuri, A., Alexander, G. C., Walker, T., Kim, S., \& Cheon, K. (2015). Evaluation of ciprofloxacin and metronidazole encapsulated biomimetic nanomatrix gel on Enterococcus faecalis and Treponema denticola. Biomaterials research, 19, 9. doi:10.1186/s40824-015-0032-4

Kikuchi, Y., \& Ishihara, K. (2021). Characterization of the Treponema denticola Virulence Factor Dentilisin. Methods in Molecular Biology, 2210, 173-184. 10.1007/978-1-0716-0939-2_17

Kikuchi, Y., Kimizuka, R., Kato, T., Okuda, K., Kokubu, E., \& Ishihara, K. (2018). Treponema denticola Induces Epithelial Barrier Dysfunction in Polarized Epithelial Cells. The Bulletin of Tokyo Dental College, 59(4), 265-275. 10.2209/tdcpublication.2017-0052

Kobiyama, K., \& Ley, K. (2018). Atherosclerosis. Circulation Research, 123(10), 1118-1120. 10.1161/CIRCRESAHA.118.313816

Kokubu, E., Inoue, T., \& Ishihara, K. (2018). Response of epithelial cells infected by Treponema denticola. Oral Diseases, 24(1-2), 14-18. 10.1111/odi.12794

Li, B., Xia, Y., \& Hu, B. (2020). Infection and atherosclerosis: TLR-dependent pathways. Cellular and Molecular Life Sciences, 77(14), 2751-2769. $10.1007 / \mathrm{s} 00018-020-03453-7$

Libby, P., Buring, J. E., Badimon, L., Hansson, G. K., Deanfield, J., Bittencourt, M. S., \& Lewis, E. F. (2019). Atherosclerosis. Nature reviews. Disease primers, 5(1), 56. 10.1038/s41572-019-0106-Z

Loyola-Rodriguez, J. P., Garcia-Cortes, J. O., Martinez-Martinez, R. E., Patiño-Marin, N., Martinez-Castañon, G. A., Zavala-Alonso, N. V., \& Amano, A. (2014). Molecular identification and antibiotic resistant bacteria isolated from primary dentition infections. Australian dental journal, 59(4), 497-503. $10.1111 /$ adj. 12213

Mahendra, J., Mahendra, L., Kurian, V. M., Jaishankar, K., \& Mythilli, R. (2009). Prevalence of periodontal pathogens in coronary atherosclerotic plaque of patients undergoing coronary artery bypass graft surgery. Journal of maxillofacial and oral surgery, 8(2), 108-113. 10.1007/s12663-009-0028-5

Maixner, F., Thomma, A., Cipollini, G., Widder, S., Rattei, T., \& Zink, A. (2014). Metagenomic analysis reveals presence of Treponema denticola in a tissue biopsy of the Iceman. Plos One, 9(6), e99994. 10.1371/journal.pone.0099994

Marttila, E., Järvensivu, A., Sorsa, T., Grenier, D., Richardson, M., Kari, K., \& Rautemaa, R. (2014). Intracellular localization of Treponema denticola chymotrypsin-like proteinase in chronic periodontitis. Journal of oral microbiology, 6.:10.3402/jom.v6.24349

Miao, D., Godovikova, V., Qian, X., Seshadrinathan, S., Kapila, Y. L., \& Fenno, J. C. (2014). Treponema denticola upregulates MMP-2 activation in periodontal ligament cells: interplay between epigenetics and periodontal infection. Archives of Oral Biology, 59(10), 1056-1064. 10.1016/j.archoralbio.2014.06.003

Middeke, M. (2019). [development, diagnosis and prevention of arteriosclerosis]. Deutsche Medizinische Wochenschrift, 144(5), 293. 10.1055/a-0796-6875

Miller, D. P., McDowell, J. V., Bell, J. K., Goetting-Minesky, M. P., Fenno, J. C., \& Marconi, R. T. (2014). Analysis of the complement sensitivity of oral treponemes and the potential influence of FH binding, FH cleavage and dentilisin activity on the pathogenesis of periodontal disease. Molecular oral microbiology, 29(5), 194-207. 10.1111/omi.12054 
Misaki, T., Fukunaga, A., Shimizu, Y., Ishikawa, A., \& Nakano, K. (2019). Possible link between dental diseases and arteriosclerosis in patients on hemodialysis. Plos One, 14(12), e0225038. 10.1371/journal.pone.0225038

Mo, S., You, M., Su, Y. C. F., Lacap-Bugler, D. C., Huo, Y., Smith, G. J. D., \& Watt, R. M. (2013). Multilocus sequence analysis of Treponema denticola strains of diverse origin. BMC Microbiology, 13, 24. 10.1186/1471-2180-13-24

Mohanty, R., Asopa, S. J., Joseph, M. D., Singh, B., Rajguru, J. P., Saidath, K., \& Sharma, U. (2019). Red complex: Polymicrobial conglomerate in oral flora: A review. Journal of family medicine and primary care, $8(11), 3480-3486.10 .4103 / \mathrm{jfmpc} . \mathrm{jfmpc}$-759_19

Nagano, K., Hasegawa, Y., Yoshida, Y., \& Yoshimura, F. (2017). Comparative analysis of motility and other properties of Treponema denticola strains. Microbial Pathogenesis, 102, 82-88. 10.1016/j.micpath.2016.11.021

Nagao, Y., \& Tanigawa, T. (2019). Red complex periodontal pathogens are risk factors for liver cirrhosis. Biomedical reports, 11(5), 199-206. $10.3892 / \mathrm{br} .2019 .1245$

Ng, H. M., Slakeski, N., Butler, C. A., Veith, P. D., Chen, Y.-Y., Liu, S. W., \& Reynolds, E. C. (2019). The Role of Treponema denticola Motility in Synergistic Biofilm Formation With Porphyromonas gingivalis. Frontiers in cellular and infection microbiology, 9, 432. doi:10.3389/fcimb.2019.00432

Paolicchi, A., Dominici, S., Pieri, L., Maellaro, E., \& Pompella, A. (2002). Glutathione catabolism as a signaling mechanism. Biochemical Pharmacology, 64(5-6), 1027-1035. 10.1016/s0006-2952(02)01173-5

Pastore, A., Federici, G., Bertini, E., \& Piemonte, F. (2003). Analysis of glutathione: implication in redox and detoxification. Clinica Chimica Acta, 333(1), 19-39. 10.1016/s0009-8981(03)00200-6

Radhakrishnan, P., Anbalagan, R., Barani, R., Mani, M., Seshadri, K. G., \& Srikanth, P. (2019). Sequencing of Porphyromonas gingivalis from saliva in patients with periodontitis and type 2 diabetes mellitus. Indian Journal of Medical Microbiology, 37(1), 54-59. 10.4103/ijmm.IJMM_18_409

Raffaelli, L., Santangelo, R., Falchetti, P., Galluccio, F., Luciani, N., Anselmi, A., \& D’Addona, A. (2010). Examination of periodontal pathogens in stenotic valve specimens and in whole blood samples in patients affected by aortic valve stenosis and chronic periodontitis. International Journal of Immunopathology and Pharmacology, 23(2), 561-566.

Rivera, M. F., Lee, J.-Y., Aneja, M., Goswami, V., Liu, L., Velsko, I. M., \& Kesavalu, L. N. (2013). Polymicrobial infection with major periodontal pathogens induced periodontal disease and aortic atherosclerosis in hyperlipidemic ApoE(null) mice. Plos One, 8(2), e57178. 10.1371/journal.pone.0057178

Rizzacasa, B., Amati, F., Romeo, F., Novelli, G., \& Mehta, J. L. (2019). Epigenetic modification in coronary atherosclerosis: JACC review topic of the week. Journal of the American College of Cardiology, 74(10), 1352-1365. 10.1016/j.jacc.2019.07.043

Ruby, J., Martin, M., Passineau, M. J., Godovikova, V., Fenno, J. C., \& Wu, H. (2018). Activation of the Innate Immune System by Treponema denticola Periplasmic Flagella through Toll-Like Receptor 2. Infection and Immunity, 86(1). 10.1128/IAI.00573-17

Soto-Barreras, U., Olvera-Rubio, J. O., Loyola-Rodriguez, J. P., Reyes-Macias, J. F., Martinez-Martinez, R. E., Patiño-Marin, N., \& Little, J. W. (2013). Peripheral arterial disease associated with caries and periodontal disease. Journal of periodontology, 84(4), 486-494. 10.1902/jop.2012.120051

Spacek, M., Zemanek, D., Hutyra, M., Sluka, M., \& Taborsky, M. (2018). Vulnerable atherosclerotic plaque - a review of current concepts and advanced imaging. Biomedical Papers of the Medical Faculty of the University Palacky, Olomouc, Czechoslovakia, 162(1), 10-17. 10.5507/bp.2018.004

Torrungruang, K., Jitpakdeebordin, S., Charatkulangkun, O., \& Gleebbua, Y. (2015). Porphyromonas gingivalis, Aggregatibacter actinomycetemcomitans, and Treponema denticola / Prevotella intermedia Co-Infection Are Associated with Severe Periodontitis in a Thai Population. Plos One, 10(8), e0136646. 10.1371/journal.pone.0136646

Toyofuku, T., Inoue, Y., Kurihara, N., Kudo, T., Jibiki, M., Sugano, N., \& Izumi, Y. (2011). Differential detection rate of periodontopathic bacteria in atherosclerosis. Surgery Today, 41(10), 1395-1400. 10.1007/s00595-010-4496-5

Velsko, I. M., Chukkapalli, S. S., Rivera-Kweh, M. F., Zheng, D., Aukhil, I., Lucas, A. R., \& Kesavalu, L. (2015). Periodontal pathogens invade gingiva and aortic adventitia and elicit inflammasome activation in $\alpha v \beta 6$ integrin-deficient mice. Infection and Immunity, 83(12), 4582-4593. 10.1128/IAI.01077-15

Verma, R. K., Rajapakse, S., Meka, A., Hamrick, C., Pola, S., Bhattacharyya, I., \& Kesavalu, L. (2010). Porphyromonas gingivalis and Treponema denticola Mixed Microbial Infection in a Rat Model of Periodontal Disease. Interdisciplinary Perspectives on Infectious Diseases, 2010, 605125. 10.1155/2010/605125 